\title{
VARIOUS BIOCHEMICAL CHANGES OF AFRICAN MARIGOLD SEEDLINGS UNDER SUGAR MILL EFFLUENT STRESS
}

\author{
Vaithiyanathan T., Sundaramoorthy P. \\ Department of Botany, Annamalai University, Annamalai Nagar-608 002 \\ Tamil Nadu, India. \\ E mail: vaithiyanathant@yahoo.in
}

Keywords: African marigold, biochemical, irrigation and sugar mill effluent.

\begin{abstract}
Sugar mill is one of the agro based industry and great significant in rural economy of developing countries. It creates environmental pollution by produced waste during sugar production. In the present work deals with the analysis of various change of biochemical in African marigold (Tagetes erecta L.) at 15 DAS under the different concentrations (control, 10, 25, 50, 75 and $100 \%$ ) of sugar mill effluent. Results of this study determined that the lower concentration $(10 \%)$ of sugar mill effluent increased photosynthetic pigment and biochemical contents of African marigold and it decreased at higher concentrations of the sugar mill effluent. The lower concentrations of sugar mill effluent used for irrigation.
\end{abstract}

\section{INTRODUCTION}

Sugar industry is the backbone of rural, agricultural and socio - economic development in India. Sugar industries rank second among the agro based industries in India. Sugar industry is seasonal in nature and operates only for 120 to 200 days in a year. A significant large amount of waste is generated during the manufacture of sugar and contains a high amount of production load particularly in items of suspended solids, organic matters, effluent, sludge, pressmud and bagasse (Muthusamy, et al., 2012). These waste waters are disposed into nearby water bodies and they are being used for irrigation. The discharge of this effluent into water bodies or on soil is causing a serious problem of water pollution resulting in severe damage to the flora and fauna and environmental degradation (Pande, 2005). Besides, the heavy metals are non-biodegradable and persist for longer periods in aquatic as well as terrestrial environments thus they can exert detrimental effect on human health and environment due to the toxicity of heavy metals (Maliwal, 2004).

Sugar mill effluents when disposed of in to the surroundings cause a severe hazard to the rural and semi-urban populations (Barman et al., 2000; Kisku et al., 2000). Sugar factory effluent has an obnoxious odour and unpleasant color when released into the environment without proper treatment. The pollutants like chloride, sulfate, phosphate, magnesium and nitrate are released with the effluent (Saranraj and Stella, 2012). Having high biological oxygen demand (BOD), chemical oxygen demand (COD), total hardness and total dissolved salts, sugar mill effluent is one of the abiotic stresses that affects the whole life cycle of plants (Doke et al., 2011). Higher concentration of sugar mill effluent could inhibit seed germination and seedling growth and eventually yield in some crops such as green gram (Baskran et al., 2009), sorghum (Doke et al., 2011), peanut (Siva Santhi and Suja Pandian, 2012). It inhibits seed germination, photosynthesis, respiration, transpiration rate, enzymatic activities, uptake and distribution of micro- and macro-nutrients in plant tissues and disturbs plant water-relationships, ionic relations, and induces free radical formation (Yildirim et al., 2006; Jauybon, 2012; Hussain, 2013).

An economical alternative to conventional methods is phytoremediation, the use of plants to physically remove contaminants from the soil (Chen, 2000). A plants ability to take up contaminants is directly related to the bioavailability of the contaminant such as a heavy metal (Shu, 2002). Ornamental plants are an important type of higher plants apart from those in the food chain, and are quite crucial if they have hyper-accumulation properties and can be applied to remediation 
of contaminated soils (Ma, 2003; Liu, 2006). Thus, using ornamentals for remediation of contaminated environment has a significant and realistic purpose (Zhou, 2006). Tagetes erecta L. Which is an herbaceous plant belonging to Compositae. Marigold (Tagetes spp.) is widely used for beautification and as landscape plants due to its ideal height and attractive colour. It is ideal for rockeries, edging, hanging baskets and in window boxes. The species is grown around field crops to control pest activity (Tereschuk et al. 1997). African marigold flowers has attractive range of colours for a considerably prolonged period and the flowers can be kept remarkably well when cut. Sometimes, the whole plant can be used for decorations. They can be planted in beds for mass display, in mixed borders and can also be grown in pots (Desai, 1967). In India, there is tremendous potential for the cultivation and use of ornamental plants and flowers because of their importance and potentiality and therefore in floriculture cultivation of this flower is receiving much attention in many countries. But the firm foundation on which this ornamental flower can be built up as and industry has to be supplied by well planned research and experimentation. In the present study was to investigate the effect of different concentrations of sugar mill effluent on photosynthetic pigments and biochemical changes of African marigold seedlings.

\section{METERIALS AND METHODS:}

\subsection{Seed material:}

Tagetes erecta L. seeds were obtained from Tamil Nadu Agricultural University (TNAU), Coimbatore, Tamil Nadu, India.

\subsection{Preparation of different concentrations of effluent:}

The collected effluent sample from the outlet of N.P.K. Ramasamy co-operative sugar mill, Thalainayar, Mayiladuthurai Taluk, Nagappattinam District, Tamil Nadu was treated as 100 per cent raw effluent. Different concentrations (10, 25, 50, 75 and 100\%) of sugar mill effluent were prepared freshly by using distilled water.

\subsection{Study of Experiments:}

The healthy and uniform sized African marigold seeds were selected and surface sterilized with $0.1 \% \mathrm{HgCl}_{2}$ for two minutes. They are thoroughly washed with tap water to avoid surface contamination. Fifty seeds were placed equidistantly in plastic cup filled with $100 \mathrm{~g}$ sterilized soil. The seeds were irrigated with equal quantity of different concentrations of effluent and the seeds irrigated with distilled water treated as control. Three replicates were maintained for each treatment including control. Chlorophyll a, chlorophyll b, total chlorophyll (Arnon, 1949), carotenoid (Kirk and Allen, 1945), reducing sugar, non-reducing sugar (Nelson, 1944), protein (Lowry et al., 1951) and amino acid (Moore and Stein, 1948) analysis were taken and recorded on the $15^{\text {th }}$ day's seedlings.

\section{STATISTICAL ANALYSIS}

Data were analyzed for one way analysis of variance (ANOVA) for determining the difference between biochemical analysis of African marigold and standard deviations were also calculated with the help of SPSS16.0 and graph formed by MS- Excel.

\section{RESULTS AND DISSCUSSION}

In the present investigation, high amount of photosynthetic pigments such as chlorophyll a, chlorophyll b, total chlorophyll and carotenoid content observed at lower concentration (10\%) of sugar mill effluent irrigated seedlings and very lowest amount of photosynthetic pigments observed at higher concentration (100\%) of sugar mill effluent treated seedlings (Figure-1). Photosynthetic pigment is one of the important factors which used as an index of production capacity of the plant. It may be due to the favourable effect of elements present in the effluent on pigment system. 
However, the photosynthetic pigment content decreased at higher concentrations of effluent. The effluent has a toxic effect on plant pigment biosynthesis during higher concentrations of sugar mill effluent irrigation. Similar observations were recorded many researchers (Divyapriya et al., 2014; Mythili and Karthikeyan, 2011; Kotteswari and Murugesan, 2014). The higher sugar content (reducing and non- reducing sugar) of African marigold seedling was observed at 10 per cent of sugar mill effluent concentration and the sugar content decreased at higher concentrations $(100 \%)$ of sugar mill effluent (Figure-2). The trend may be due to the lesser starch content in higher concentrations effluent treatment which implies the starch metabolism and poor translocation of sugar to growing part. The excess of nitrogen, sodium and chloride present in the effluent inhibit the uptake of other elements like magnesium, potassium and phosphorus by the plant. The deficiency of magnesium and the resultant chlorosis reduced the photosynthetic rate which is turn decreased the carbohydrate and starch content of crop plant. The similar observations were also reported by Ayyasamy, 2008; Divyapriya et al., 2014. The increase in protein content of Tagetes erecta L. seedlings was observed at lower concentration of sugar mill effluent. The highest protein content was recorded at 10 per cent concentration of effluent (Figure-2). It might be due to absorption of most of the necessary elements by plant. At the same time, the protein content decreased with the increase of sugar mill effluent concentration. It has been reported that high concentrations of various cations and anions present in the effluent caused the decrease in protein content (Suresh, 2014). Optimum level of magnesium is also essential to maintain the structure of ribosomes and ribonucleic protein bodies which are essential for protein synthesis. The amino acid content of African marigold seedlings increased at 10 per cent and then decreased at higher concentrations of sugar mill effluent (Figure-2). Similar observations were also reported by Baskaran et al., 2009; Divyapriya et al., 2014 on different plants treated with industrial effluent. The decrease in amino acid content in the treated seedlings can be attributed to the inhibitory effect of the effluent on protease activity.

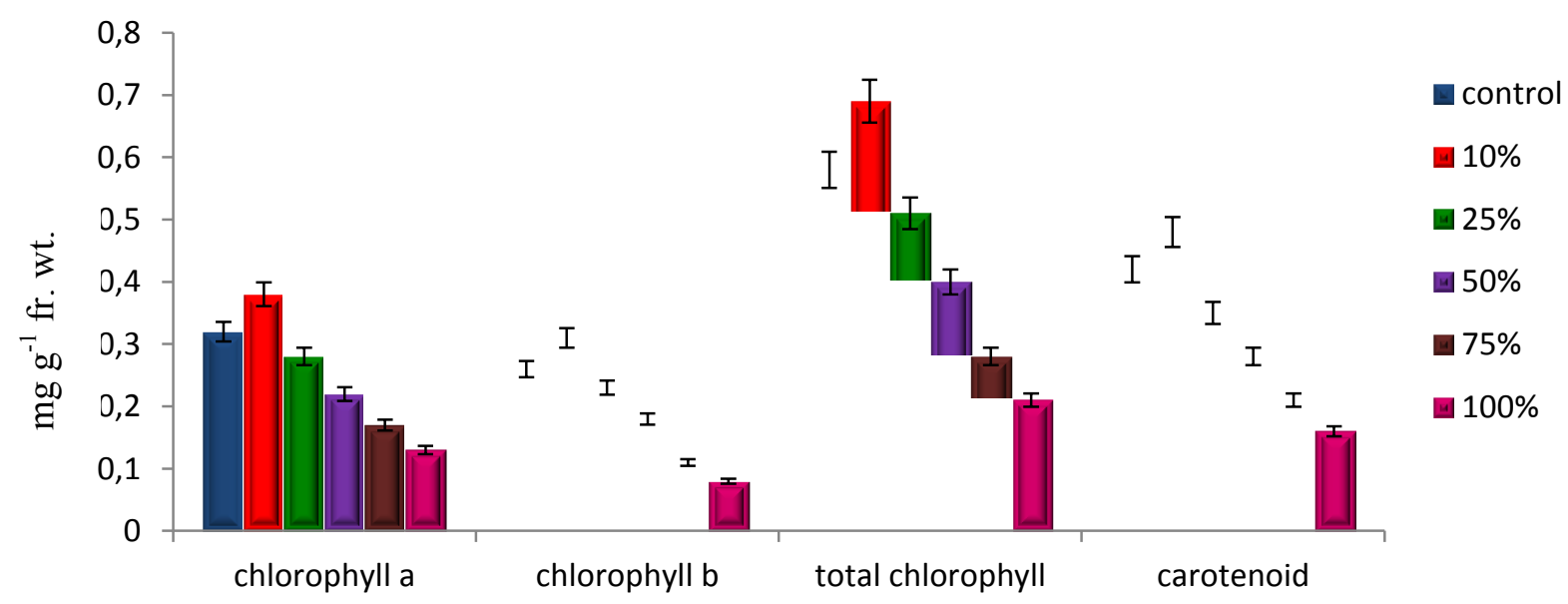

Concentrations of sugar mill effluent

Figure-1. Photosynthetic pigments of African marigold (Tagetes erecta L.) grow under different concentrations of sugar mill effluent. 


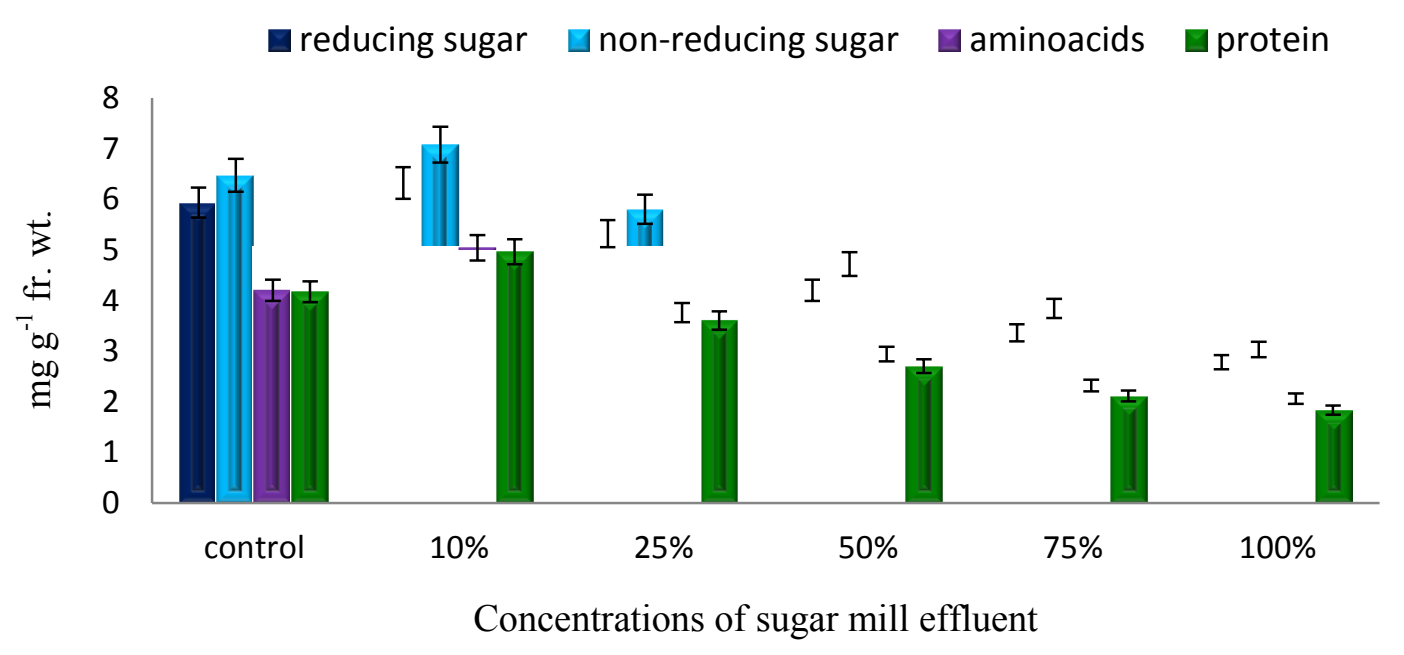

Figure-2. Biochemical analyses of African marigold (Tagetes erecta L.) grow under different concentrations of sugar mill effluent.

\section{CONCLUSION}

In the present study concluded that the lower concentration $(10 \%)$ of effluent promoted the biochemical content of the African marigold seedlings and it gradually decreased with increased of effluent irrigation. The favourable amount of plant nutrients may be present in the lower concentration of sugar mill effluent. The lower concentration $(10 \%)$ of sugar mill effluent use for irrigation purposes which use as a fertilizer.

\section{ACKNOWLEDGEMENT}

The authors are thankful to Professor and Head, Department of Botany, Annamalai University for providing laboratory facilities to carry out these experiments.

\section{Reference}

[1] Arnon, D. J., Plant Physiol. 24 (1949) 1-15.

[2] Ayyasamy, P.M., R. Yasodha, S. Rajakumar, P. Lakshmanaperumalsamy, S. Rahman Lee, Inter. Bull. Environ. Contam. Toxi. 81 (2008) 449- 454.

[3] Barman, S.C., R.K. Sahu, S.K. Bhargava, C. Chatterjee, Bull. Environ. Contam. Toxicol., 64 (2000) 489-496.

[4] Baskran, L., P. Sundaramoorthy, A.L.A. Chidambaram, K. Sankar Ganesh, Bot. Res. Int., 2 (2009) 107-114.

[5] Chen, H.M., C.R. Zheng, C. Tu, Z.G. Shen, Journal of Chemosphere. 41(1-2) (2000) 229-234.

[6] Desai, B.L., Indian Agricultural Research Institute, New Delhi, (1967).

[7] Divyapriya, S., Dimi Divakaran, P.K. Deepthi, Int. J. Pharm. Pharm. Sci., 6(2) (2014) 538-542.

[8] Doke, K.M., M.E. Khan, J. Rapolu, A. Shaikh, Ann. Environ. Sci., 5 (2011) 7-11.

[9] Hussain, I., M. Iqbal, M. Nawaz, R. Rasheed, A. Perveen, S. Mahmood, A. Yasmeen, A. Wahid, Int. J. Agric. Biol., 15 (2013) 1227-1235.

[10] Jauybon, Z., Tech. J. Engin. App. Sci., 2 (2012) 7-10.

[11] Kirk J. T. O., R. L. Allen, Biochem. Biophys. Res. Cann. 27 (1965) 523-530. 
[12] Kisku, G.C., S.C. Barman, S.K. Bhargava, Water Air Soil Pollut., 120 (2000) 121-137.

[13] Kotteswari, M., S. Murugesan, World Journal of Pharmacy and Pharmaceutical Sciences, 3(6) (2014) 811-821.

[14] Liu, J.N., Q.X. Zhou, X.F. Wang, Q.R. Zhang, T. Sun, Global Science Books, London, (2006) $245-252$.

[15] Lowry O. N., N. J. Roserbrough, A. L. Farr, R. J. Randell, J. Biol. Chem. 193 (1951) 265-275.

[16] Ma, Y.L., Journal of Chang Chun University, 13 (2003) 21-29.

[17] Maliwal, G.L., K.P. Patel, K.C. Patel, M.N. Patel, Pollution Research, 14 (2004) 231-238.

[18] Moore S., W.H. Stein, J. Biol. Chem. (1948) 176-388.

[19] Muthusamy P., S. Murugan, Manothi Smitha, ISCA Journal of Biological Sciences, 1(2) (2012) 7-11.

[20] Mythili, K., B. Karthikeyan, Current Botany, 2(8) (2011) 40-45.

[21] Nelson, N., Anal. Chem. 3 (1944) 426-428.

[22] Pande, Y.N., Ecology and Environmental, 1(4) (2005) 39-42.

[23] Saranraj, P., D. Stella, Int. J. Pharmaceut. Biol. Arch., 3 (2012) 1121-1128.

[24] Shu, W.S., Z.H. Ye, C.Y. Lan, Z.Q. Zhang, M.H. Wong, Journal of Environmental Pollution. 120(2) (2002) 445-453.

[25] Siva Santhi, K., R. Suja Pandian, Int. J. Pharm. Chem. Sci., 1 (2012) 804-806.

[26] Suresh, B., K. Abraham, T. Damodharam, Adv. Appl. Sci. Res., 5(5) (2014) 305-309.

[27] Tereschuk, M.L., M.V. Riera, G.R. Castro, L.R. Abdala, J. Ethnopharmacol. 56 (1997) 22732.

[28] Yildirim, E., A. G. Taylor and T.D. Spittler, Sci. Hort., 111 (2006) 1-6.

[29] Zhou, Q.X., Journal of Environmental Chemistry, 25 (2006) 257-265. 